\title{
Imaginative migrations: An interview with the Lebanese-Canadian writer Rawi Hage
}

\section{Rita Sakr}

To cite this article: Rita Sakr (2011) Imaginative migrations: An interview with the Lebanese-Canadian writer Rawi Hage, Journal of Postcolonial Writing, 47:3, 343-351, DOI: 10.1080/17449855.2010.534617

To link to this article: https://doi.org/10.1080/17449855.2010.534617

曲 Published online: 30 Nov 2010.

Submit your article to this journal $\pi$

Џll Article views: 464

Q View related articles $\asymp$

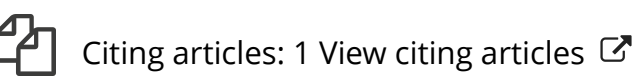




\title{
Imaginative migrations: An interview with the Lebanese-Canadian writer Rawi Hage
}

\author{
Rita Sakr* \\ University of Sherbrooke, Canada
}

\begin{abstract}
The history of mankind is full of wars, divisions, the flow of blood, the flight of refugees and misery. I long for the day when an African child will be able to roam the world as if it is rightly his; I long for the day when Palestinian, Guatemalan, Iraqi and Afghan children will have homes to keep and build upon. I long for the day when we humans realize that we are all gatherers and wanderers, ever bound to cross each other's paths, and that these paths belong to us all. (From Hage's Acceptance Speech at the 2008 International IMPAC Dublin Literary Award ceremony)
\end{abstract}

Keywords: novel; intercultural; migration; trauma; violence; war

\section{Introduction}

Rawi Hage is a Lebanese-Canadian novelist, visual artist, photographer, and curator born in Beirut, where he lived through the war years until 1984 when, like thousands of Lebanese people who emigrated to escape the conflict, he left for New York City. ${ }^{1}$ He then immigrated to Canada and has been living there since 1992. He now resides, works and writes in Montreal. Boosted by training at Dawson College and Concordia University and by growing fame in art circles, he exhibited his work as a photographer and visual artist in the Canadian Museum of Civilization, the Musée de la civilization - Québec, and in galleries around the world. While fragments of writing feature as an essential element in Hage's artwork, his practice of visual art and photography has strongly influenced his novelistic technique, which is remarkably imagistic and filmic. ${ }^{2}$

An Arab francophone who now belongs to a select niche of award-winning anglophone novelists, Hage began his literary production with short stories that were published in small magazines. His writings appeared in Fuse, Minza, Jouvert, The Toronto Review, The New Quarterly, Montreal Serai, and al Jadid, among others. For his first novel, De Niro's Game, which grew out of a short story, he received, among many other honours, the 2008 International IMPAC Dublin Literary Award (in a competition that involved Margaret Atwood, Thomas Pynchon, Philip Roth, and Ngugi wa Thiong'o), the McAuslan First Book Prize and being shortlisted for the Scotiabank Giller Prize, the Governor General's Literary Award for Fiction, and the Commonwealth Writers' Prize for Best First Book. With a title that draws inspiration from the Russian roulette scene in Michael Cimino's 1978 Vietnam film drama The Deer Hunter, De Niro's Game depicts the nightmarish experiences and fragile aspirations of two young friends, Bassam and George (aka De Niro), in war-torn Beirut, where survival involves the dangerous games of militias and religious tribalism. ${ }^{3}$ A tale of friendship, love, betrayal, massacre, doomsday chaos and

*Email: rsakr1@gmial.com 
diverted dreams in a city under siege, De Niro's Game is divided into three parts "Rome"; "Beirut"; "Paris" - which become geopolitical and symbolical signposts intersecting along the narrator's journey. This riveting journey ends with Bassam escaping Beirut to Paris, where a tangled web of personal and political secrets is unraveled only to send our anti-hero on a journey to Rome, the suggestive dream destination that occupied his mind in Beirut. De Niro's Game was translated into more than 20 languages, including Arabic. The French translation, Parfum de poussière, won Le Prix des Libraires du Québec in 2008 and Le Combat des livres in 2009, while the German translation, Als ob es kein Morgen gäbe, was shortlisted for the first International Literature Prize from the Haus der Kulturen der Welt.

Cockroach, his highly acclaimed second novel, which has frequently been read as a sequel to the first, ${ }^{4}$ explores the material and psychological trials of an immigrant who carries the traumatic wounds of a violent war in his unnamed country into an only apparently peaceful Montreal where he discovers that the "[s]oftness [of snow, intercultural relations, and socio-economic security] is temporary and deceiving" (Cockroach 249). For T.F. Rigelhof, "[t]he things that make Rawi Hage a major literary talent - and Cockroach as essential reading as its predecessor - include freshness, gut-wrenching lyricism, boldness, emotional restraint, intellectual depth, historical sense, political subversiveness and uncompromising compassion" (n. pag.). Like De Niro's Game in 2006, Cockroach was nominated for the Giller and Governor General's awards and won in 2008 the Paragraphe Hugh MacLennan Prize for Fiction awarded by the Quebec Writers' Federation. It has been translated into 18 languages (including Arabic) and was on the 2010 IMPAC Dublin longlist along with two other novels written also in 2008 by Lebanese writers, directly and indirectly recounting the Lebanese war and its repercussions: A Girl Made of Dust by Nathalie Abi-Ezzi and The Hakawati by Rabih Alameddine. Like Alameddine and Abi-Ezzi, Hage belongs to the growing number of diasporic Lebanese novelists writing in English and contributing multiple perspectives on the wartime and post-war realities of the Lebanese inside and outside of Lebanon (Canada, Australia, the United Kingdom and the United States). ${ }^{5}$

Trauma pervades both the subject and style of Hage's writings. While the almost dehumanizing experiences of a physically and psychologically damaging war mark the plot and characters of De Niro's Game, the unsettling journey of immigration into an emotionally and materially cold environment (where Cockroach's narrator is alienated from almost everyone: his naive court-appointed therapist who relishes his "stories" of a homeland ravaged by war; his fellow immigrants who enter poor clinics to "say 'Ahh' with an accent, [and] expose the whites of their droopy, malarial eyes" (Cockroach 79); the rich Quebecois from whom he grudgingly steals and to whom he sells over-priced drugs; and Montreal's winter, which he imagines as telling him "with tight lips and a cold tone [ ... ] to go back where $[\ldots]$ [he] came from if [ ... ] [he does] not like it here" [193]) only serves to aggravate the impact of past traumatic experiences on the narrator's tormented psyche. In an article titled "Apocalyptic Narrative Recalls and the Human: Rawi Hage's De Niro's Game", Najat Rahman approaches Hage's novel astutely as "an alternative imagining in a narrative traumatic recall that exposes the repercussions of violence and allows for a vision of history where the human's quest for freedom and relation opens to a future" (801). In Cockroach, the imagined "future" of trauma is articulated within a framework of epistemological and ontological indeterminacy in relation to personal and historical violence, and hence can be described in terms of what Cathy Caruth defines as a "crisis of truth" (8), where the only form of freedom is imaginative - a fictional "underground" where metaphorical cockroaches abound. Hage expresses this crisis by 
blurring the boundaries between the narrator's real experiences, memories, fantasies, and hallucinations as he painfully grapples with past and present wounds and as he seeks an identity, a space, and a life at the border of physical and psychological death - the death of his sister and of numerous others in his war-torn country and his attempted suicide and deterioration in Montreal. (Sakr)

This traumatic texture is expressed in the style of both novels: grippingly cinematic and blending an almost obsessive figurative energy with cynically dark humour and rawly violent prose that bombards the reader with 10,000 images - the stylistic equivalent of the "ten thousand bombs" that haunt Beirut and the narrator in De Niro's Game. Most reviewers of Hage's writing have noted its lyrical but also hallucinatory, cinematic style. For James Lasdun, "[t]he style is what you notice first in both books, its salient feature being a kind of compulsive efflorescence of imagery at everything the narrator's mind settles on" (11). While the narrator's mind leaves us with 10,000 disturbing images, the heterogeneous style of Hage's novels and the myriad territories that his work traverses are so imaginatively unsettling that they thwart the attempts of critics, reviewers, and interviewers to classify his work. When he accepted the IMPAC Dublin Literary Award for De Niro's Game, Hage described his personal and literary identity as that of a "wanderer" and a "global citizen":

Born as a Christian Arab, a group whose existence is an integral part of a great Arabic and Islamic civilization, I grew up learning two languages and different histories, and at the age of eighteen learned the English language and imbibed the canon of its great poets and writers. Later, as a traveler, a citizen, a worker, a reader, and a writer, I was, fortunately, bound to become a global citizen. ("Acceptance Speech" n. pag.)

Challenging boundaries and promising yet more transcultural imaginative feats, Hage is now writing his third novel.

In a recent review of Hage's Cockroach for The New York Times, Mary Gaitskill, reluctantly praising the novel's "whimsy, which sometimes becomes genuine earthy charm", undermines the critical tendency to compare Hage's work to "Dostoyevsky, Kafka, Genet, Rimbaud and Burroughs" and finally "wonder[s] at how extravagantly he's been praised and at how fast he's been elevated to the status of an internationally important author" (par. 10). Less to uncover the mysteries of his envied commercial and critical success than to discover the writer's own response to the various aesthetic, political, and social questions his brilliant work raises, I met him at a café in Montreal in November 2009. ${ }^{6}$ We discussed his novels in relation to issues of literary identity and classification, literary style, philosophical subtexts, the representation of violence, trauma, intercultural conflicts, and the functions of the novel. Lebanese Arabic and English were used during the interview and I subsequently translated the conversation. Rawi Hage accepted the final English version (below), which is based on his translated and paraphrased statements.

RS Hello, Rawi. It is a great pleasure to meet you after reading your work which, for me, evokes the pains and pleasures of myriad migrations. A reader can feel that the literary identity of your work playfully migrates among different spaces: Canadian, Quebecois, contemporary Lebanese, Middle Eastern, Arabic, post-war, minority, and diasporic literatures. Yet it does not settle within any particular framework and maintains a fluid multiplicity. What do you think of the categories within which readers and critics have placed your novels? As a reader of your own work, how would you describe its identity? 
RH I find that categories oftentimes homogenize and simplify literary texts which are complex and multilayered. That is why I am disturbed when ambiguous, simplistic, or monolithic definitions are attached to my novels. I have noted that critics and reviewers sometimes focus exclusively on one aspect, motif, or detail in my work and thus overlook the multiple other important dimensions and meanings that it comprises or suggests. I think that I need to educate or guide my readers with respect to the multilayered texture of my writings. As an individual born and raised in Lebanon, I was influenced by the crisis of identity and the conflictual nature of the question of belonging in that nation with its myriad denominations, historical layers, and geopolitical relations. As a result, my imaginative perspective transcends exclusionary regionalities, clear-cut historical frameworks, or unidimensional approaches. This is why many of my readers' expectations are thwarted when they are confronted with the multifaceted nature of my work. I would say that it is hard to claim me. The secularist ethos that underlies both of my novels perhaps best describes the identity of my work, which needs to be assessed from a broad and manifold perspective. For instance, in Cockroach, I appropriate religious aesthetics particularly in the sense that the novel consists of three imaginative and metaphorical levels that have combined mythical and religious significance wherein the underground/underworld has a centrally symbolic importance. At the same time, I am using this religiously significant schema to subvert religious dogma from within.

RS Your novels express a textual and stylistic hybridity whereby the figurative energy and lyricism of Arabic poetry blend with the psychologically somber atmosphere of Fyodor Dostoevsky's and Knut Hamsun's works, the fiercely sarcastic notes and apocalyptic anxieties of much contemporary anglophone prose, and the visual and cinematic effects of postmodern literature. In what ways do you think such hybridity affects an internationally broad readership? What does this hybridity communicate in response to political and literary nationalisms?

$\mathrm{RH}$ I think that reading my novels requires a great degree of openness and a readiness to move beyond the cliché of "humanity" to really engage with the kind of internationalism that they articulate. My writings appeal to a global - and not globalized - audience because they suggest numerous references across time and space and because they elicit a keen political and historical awareness. History and geopolitics are volatile, convoluted, and tainted. In response to that, my work is a satire of nationalisms that range from the totalitarian versions that thrive at the expense of the general poverty which they neglect to the democratic versions that are in fact exclusionary and economically exploitative in various ways.

RS Are you at all concerned by the fact that not all readers can capture the cultural specificity and nuances of the Arabic literary impact on your style?

RH For a novel to be successful, I don't think that it is necessary for readers to unravel all its mysteries. I acknowledge the impact of Arabic poetry on my style, but I believe that it is one influence among many that are present in different ways in my writings.

\section{RS Do you still read Arabic literature/poetry?}

RH In the past I used to avidly read Arabic literature in addition to other literatures. However, a gap has now emerged between me and Arabic literary texts specifically. Still, I am interested in the political issues in the Arab world and follow news on it in the media. 
RS There is an implied philosophical subtext that lends your works a significance which transcends the geographical and historical frameworks in which they are situated. How would you describe the philosophical dimension of your writings?

RH Although I don't have an explicit or systematic philosophical agenda, the philosophical implications of my work emerge loosely from the narrative and from the relations between the characters and their perspectives. I believe that the philosophical messages of a novel should not be prepared and methodically formulated before the act of writing. A literary text is the result of an intellectual and experiential maturity that insures its relevance and significance for the readers. In addition to maturity, it is crucial to have and to express a genuine concern for the world, society, individuals and the effect of ideologies on them. Although fiction should not start with the political or philosophical, it communicates a desire to tell, a creative impulse that is largely fuelled by concern.

RS De Niro's Game and Cockroach deal with explicit and implicit violence in different geopolitical contexts. The weapons of De Niro's Game seem to be muted and concealed but unmistakably present in the underground world of Cockroach 's Montreal. In the international game of war, how can a novel tactically engage a culture of violence?

$\mathrm{RH}$ What marked me most was the experience of displacement from war-torn Lebanon. After immigrating, De Niro's Game was my imaginative return to Beirut and its war. I am convinced that the poetic is not far from violence. The depiction of violence in literature was freely permitted before Christianity gave the illusion of passivity and peacefulness (Homer is an example). As a result, authors became skilled at veiling the violence that is unquestionably present everywhere. I don't conceal violence. I see humans as wanderers, survivors, and hunter-gatherers and I represent this basic instinctual level in my writings. I strip my characters and present their raw animalistic essence. My characters are not hypocritical; they epitomize the complexity of the human being whose breadth and depth carry a violence that is both primitive and contemporaneous. This is the multilayered complexity of Cockroach's human vision.

RS In this way your writing can be described as historically contrapuntal.

RH Yes, I fuse the past and the present, thus undermining any narrative homogeneity. My texts comprise various turns and movements between spaces and times without disrupting the flow of narration.

RS Violence is also deeply felt in the style, language, and images that you employ. Some passages in De Niro's Game have the visual immediacy of war photography. To what extent does your work as a visual artist and photographer affect your writing?

RH I think that my knowledge and experience in the field of photography are translated in the way that the images are framed and captured with a great degree of immediacy in my novels. Just as in photography, I start by situating myself in proximity to a space or within it; in my novels I emphasize an imaginative sense of my physical presence in that space. I then combine images into the narrative without explaining them. In this respect, I make a leap of faith that the reader would understand.

RS The 1982 Siege of Beirut was represented by a diverse group of writers, journalists, artists, and filmmakers. De Niro's Game renders the atrocity of the Siege with both 
historical precision and imaginative vividness. What are the ethical parameters of representation for a writer in relation to a macro-historically significant traumatic event which he has personally experienced and which he reimagines in a fictionalized version? How does a novelist's rendering of such an event compare with a journalist's reportage?

RH Unlike a journalist, I have no contract with the reader to tell the exact truth. My representation of the Siege is not a documentary work. Still, De Niro's Game is engaged in the representation of a contested war and a contested history. When it was first published, I thought that it would get a harsher response in the Middle East and in my community in Lebanon specifically. With this work, I was faced with an ethical choice: either to take secularism to its ultimate test and go beyond my communal belonging, or apply censorship to my narrative. I chose the first option and eventually wasn't criticized by the readership that would have normally condemned the novel. Ironically, I think that literary prizes sometimes contribute to lessening the anger of outraged readers and to forgiving a writer's "sins" in representing the unrepresentable. A writer can seldom play the role of the reformer without contributing to stereotypes. That is why he/she must be cautious and must enlarge the perspective of representation in such a way that local and regional conflicts are transposed onto international matrices. This is especially relevant to a representation of the Lebanese war and its traumatic events since Lebanese history and geography cannot be dissociated from a multiplicity of "others" and of foreign cultures that have affected the country in both positive and negative ways. On this basis, the functions of "Paris" and "Rome" in the novel are manifold, and their symbolic resonances are couched in ambiguity. Among its many implications, Paris evokes France's colonial relations with Lebanon and especially with the Maronites, who for a long time remained attached to it and were at times disappointed by it. Rome may signify a final destiny or death.

RS The Lebanese Civil War has not been officially historicized, nor has a war memorial been erected to commemorate the victims. How do you respond to a reading of $D e$ Niro's Game as a counter-monumental work that imaginatively unleashes its "one thousand bombs" on the repressed and suppressed cultural memory of Lebanon?

RH De Niro's Game offers a thin slice of memory rather than a finalized and fixed history. In this sense it is counter-monumental and contributes to a different project of memorialization. Instead of historical documentation, I show the mechanism of war and the binaries which initiate and sustain conflict.

RS Physical and psychological wounds also mark the characters in Cockroach, which vividly and poignantly dramatizes the personal and historical trauma of its protagonist whose "stories" of violence both lure and confound his government-appointed therapist. The novel thus invites questions about ethical responsibility in treating trauma victims who escape conflict situations and seek refuge in other nations.

RH Cockroach focuses on the themes of immigration and mental illness. In this respect, my novel implicitly satirizes the western culture of confession. For Foucault, psychoanalysis is an extension of the culture of confession and is an institutionalized version of it. Cockroach reveals how impersonal and intrusive such cultures and institutions are. The main character's silence is violated as he is pushed by his therapist to tell his "stories" but, at the same time, this process of telling is essential to the narration of the traumatic experiences that the characters endured. This is the inevitable paradox of narration. 
RS If traumatizing situations can be escaped physically, can they be fully overcome on psychological and imaginative levels?

RH Through temporal and spatial distance, traumatic experiences can be made less present and less oppressive. However, these experiences inevitably become part of one's personal history and identity. They must be reassessed and revalued on an individual level. As they are revealed, they can be imaginatively reformulated and reused in a potentially positive manner. The latent and the repressed can be dangerous. However, the process of dealing with trauma and letting the wounds surface must transcend the boundaries of the collectivity wherein public confession is closely linked to public duty and public good.

RS Cockroach presents instances of misunderstanding, naivety, and distrust in intercultural relations. To what extent do you share this pessimistic vision with respect to the future of immigrant communities and host nations?

$\mathrm{RH}$ I think that in all intercultural relations there is an initial encounter that is difficult and an initial period of malaise and misunderstanding that is followed by a period of getting to know the "other". Several generations must pass by before full integration is achieved, and eventually consensus must be sought and accomplished in multicultural societies. All identities start with multiplicity until some consensus is reached. Nevertheless, integration is fragile and fake if egalitarian values are not unequivocally established.

RS Concluding a review of Cockroach for The Guardian, James Lasdun says that "if, a little later, you find yourself feeling that the book has after all raised more questions about the condition of wretchedness than its ending quite resolves, this is only further evidence of Hage's large and unsettling talent" (11). Cockroach is deeply concerned with class, economic disempowerment, unemployment, and misery among various groups of immigrants. As a closure to our multifaceted conversation today, how do you define your role as a novelist with respect to the panorama of social injustice that your work depicts?

RH Since the novel has a longer life and wider reach than a sociological or historical study, it can have an influential role as it becomes part of the truth. My novels don't change the world but they create an awareness of possibilities and hence might [Hage's emphasis] contribute to change.

\section{Notes}

1. The war in Lebanon lasted from 1975 to 1990 . As a result, "[a]bout 170,000 people have perished; twice as many were wounded or disabled; close to two thirds of the population experienced some form of dislocation or uprootedness from their homes and communities" (Khalaf 232).

2. Zuzana Kratka notes these influences in her review of De Niro's Game, "Living with Civil War".

3. A self-made secularist, Hage was born and raised as a Maronite Christian. In an interview with Arts \& Opinion, Hage reflects on the "tribal loyalties" that harmed religious coexistence in Lebanon, and he defines his secularism as "no longer relat[ing] positively or negatively to people or groupings of people based on their religion or ethnicity. I much prefer to be in community with people with whom I share common values and morals or ideology" (n. pag.).

4. See T.F. Rigelhof's "Howls from the Underdogs", James Lasdun's "Half Man, Half Insect", and Colm Tóibín's "The Anger of Exile". These three reviews of Cockroach establish a link between the narrators of Hage's two novels and a continuity between their respective fictional journeys. Lasdun and Tóibín emphasize the theme of exile underlying this link. 
5. These include Jad El-Hage, Tony Hanania, Patricia Sarrafian Ward, and Nada Awar Jarrar. The tradition of anglophone diasporic and exiled Lebanese writers began in the early 20th century with the Lebanese-American Gibran Khalil Gibran. This cultural diaspora expanded significantly in the wartime and post-war years due to an emigration trend that resulted mainly from the physical, psychological, and socio-economic ravages of the Lebanese war.

6. There are numerous interviews with Rawi Hage: email and audio conversations (for example with CBC News and its cultural affairs show $Q$, and with Nigel Beale, and interviews of various length in newspapers and magazines: Arts \& Opinion, Nox, Le Devoir, Le Monde, La Presse, The Daily Star - Lebanon, and many others. Although it complements the previous conversations with Hage, my interview differs considerably from these because it employs a multidisciplinary scholarly perspective to shed light on the links between the aesthetic/literary and the philosophical, psychological, and socio-political dimensions of his writings.

\section{Notes on contributor}

Rita Sakr teaches at the University of Sherbrooke, Canada. Her work on Middle Eastern literatures, James Joyce, and literary geographies is published in several journals and collections of essays. She is the author of the forthcoming monograph Monumental Space in the Post-Imperial Novel. With Finn Fordham, she is the co-editor of James Joyce and the Nineteenth-Century French Novel and, with Caroline Rooney, she is co-editing The Siege of Beirut and the Ethics of Representation.

\section{Works cited}

Abi-Ezzi, Nathalie. A Girl Made of Dust. London: Fourth Estate, 2008.

Alameddine, Rabih. The Hakawati. New York: Knopf, 2008.

Beale, Nigel. "Audio Interview with Rawi Hage: 2008 IMPAC Award Winner." 12 June 2008. 4 Oct. $2010<$ http://nigelbeale.com/2008/06/12/audio-interview-with-rawi-hage-2008-impacaward-winner $>$.

Birke, Sarah. "Rawi Hage and the Practiced Art of Imagined Proximity." The Daily Star - Lebanon 4 Aug. 2008: 10.

Caruth, Cathy. "Introduction: Trauma and Experience." Trauma: Explorations in Memory. Ed. Cathy Caruth. Baltimore, MD: Johns Hopkins UP, 1995. 3-12.

Chong, Kevin. “A Bug's Life.” Telephone Interview. CBC News 25 Aug. 2008. 4 Oct. 2010 $<$ http://www.cbc.ca/arts/books/story/2008/08/25/f-rawi-hage-cockroach.html>.

Gaitskill, Mary. "Angels and Insects." The New York Times 12 Nov. 2009. 1 Feb. 2010. $<$ http://www.nytimes.com/2009/11/15/books/review/Gaitskill-t.html $>$.

Ghomeshi, Jian. “Audio Interview with Rawi Hage.” $Q$ show on CBC Radio 30 Oct. 2008.

Hage, Rawi. Als ob es kein Morgen gäbe. Trans. Gregor Hens. Cologne: DuMont, 2009.

- Cockroach. Toronto: Anansi, 2008.

. De Niro's Game. Toronto: Anansi, 2006.

Interview. Arts \& Opinion 6.3 (2007). 9 Oct. $2010<\mathrm{http} / / / \mathrm{www}$. artsandopinion.com/ 2007_v6_n3/hage.htm>.

. Interview with Chantal Guy. "Rawi Hage: le blues de la blatte." La Presse 9 Oct. 2009. 1

Feb. $2010<$ http://www.cyberpresse.ca/arts/livres/entrevues/200910/09/01-909892-rawi-hage-leblues-de-la-blatte.php>.

—. Interview with Eddie Taylor. "A Conversation with Rawi Hage.” Nox Feb. 2007. Rpt. in De Niro's Game. New York: Harper, 2008.

- Parfum de poussière. Trans. Sophie Voillot. Montreal: Alto, 2007.

. Rawi Hage's Acceptance Speech June 2008. 15 Feb. $2010<$ www.impacdublinaward.ie/ 2008/Rawi\%20Hage\%20Speech.doc>.

Khalaf, Samir. Civil and Uncivil Violence in Lebanon: A History of the Internationalization of Communal Conflict. New York: Columbia UP, 2002.

Kratka, Zuzana. "Living with Civil War." Banipal 28 (Spring 2007).

Lasdun, James. "Half Man, Half Insect." The Guardian 23 May 2009: 11.

Montpetit, Caroline. "Rawi Hage - Survivre à son passé." Le Devoir 3-4 Oct. 2009: 1 (F1).

Rahman, Najat. "Apocalyptic Narrative Recalls and the Human: Rawi Hage's De Niro's Game." University of Toronto Quarterly 78.2 (2009): 800-14. 
Rigelhof, T.F. "Howls from the Underdogs." Globe and Mail 30 Aug. 2008. 10 Feb. $2010<$ http:// www.theglobeandmail.com/books/howls-from-the-underdogs/article50511>.

Rousseau, Christine. "La Tragédie du Liban; c'est l'amnésie." Le Monde 24 Oct. 2008: 8.

Sakr, Rita. "Heterotopia and its Discontents: Exploring Spatial, Cultural, and Textual Liminality in Rawi Hage's Cockroach." Contested Spaces: Conflict, Counter-Narrative, and Culture from Below in Canadian and Québécois Literatures. Ed. Roxanne Rimstead and Domenic A. Beneventi. Toronto: U of Toronto P (forthcoming).

Tóibín, Colm. "The Anger of Exile: Review of The Hakawati by Rabih Alameddine and Cockroach by Rawi Hage." The New York Review of Books 57.5 (25 Mar. 2010) 30 Mar. $2010<\mathrm{http}: / /$ www.nybooks.com/articles/23732>. 